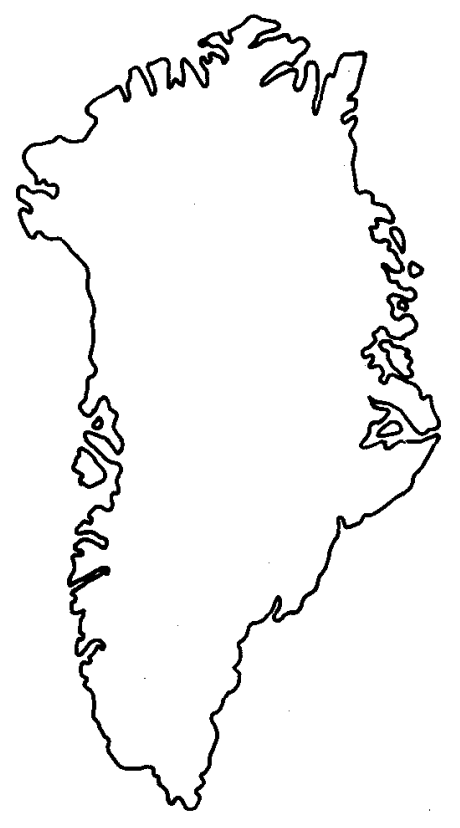

\title{
Slope apron and deep shelf sediments of the Brønlund Fjord and Tavsens Iskappe Groups (Lower Cambrian - Lower Ordovician), North Greenland: stratigraphy, facies and depositional setting
}

\author{
Jon R. Ineson, Finn Surlyk, A. K. Higgins \\ and John S. Peel
}

During most of the early Palaeozoic, the Franklinian Basin in North Greenland was composed of a southern shelf and a northern deep-water basin. From the late Early Cambrian to the Early Ordovician, the shelf displayed a stepped, terraced profile with two discrete breaks in slope. These occurred at the platform edge and at the boundary between the outer shelf and the deep-water turbidite basin. The transect from platform margin to deep outer shelf is recorded by the carbonate and siliciclastic sediments of the Brønlund Fjord and Tavsens Iskappe Groups (Lower Cambrian - Lower Ordovician). The platform margin and flanking carbonate slope apron are preserved in the southern outcrop belt, trending east-west parallel to the margin of the Greenland Inland Ice. Some 50-100 km farther north, strata of equivalent age reappear in an outcrop belt that follows the northern coastline of western and central North Greenland; these strata document the transition from slope apron to deep-water outermost shelf or upper slope.

In this northern outcrop belt, the Brønlund Fjord Group comprises two formations, the Aftenstjernes $\emptyset$ Formation (Lower Cambrian) and the Henson Gletscher Formation (Lower-Middle Cambrian), as defined from the southern outcrop belt. The Tavsens Iskappe Group consists of a single formation defined here as the Kap Stanton Formation (Middle Cambrian - Lower Ordovician). The Brønlund Fjord and Tavsens Iskappe Groups in the northern outcrop belt are dominated by dark-coloured finegrained sediments ranging in composition from lime mudstones through marlstones to cherty calcareous or dolomitic siliciclastic mudstones. Graded and cross-laminated lime grainstones and packstones are locally important and carbonate breccia beds up to several tens of metres thick dominate some sections and form persistent marker beds at certain stratigraphic levels. These facies record deposition from suspension, mud-rich turbidity currents, slides and debris flows in a slope apron to deep shelf setting.

The northern outcrop belt of the Brønlund Fjord and Tavsens Iskappe Groups represents an oblique section through the Cambrian outer shelf from proximal slope apron in the west to deep outermost shelf in the east. Although the western platform margin is not exposed, these deeper-water shelf deposits testify to a history of intermittent platform progradation during the Middle and early Late Cambrian followed by aggradation of the platform during the latest Cambrian and the Early Ordovician.

J. R. I., Geological Survey of Denmark, Thoravej 8, DK-2400 Copenhagen NV, Denmark.

F. S., Geological Institute, University of Copenhagen, Øster Voldgade 10, DK-1350 Copenhagen K, Denmark.

A. K. H., Geological Survey of Greenland, Øster Voldgade 10, DK-1350 Copenhagen $K$, Denmark.

J. S. P., Dept of Historical Geology \& Palaeontology, Institute of Earth Sciences, Uppsala University, Norbyvägen 22, S-752 36 Uppsala, Sweden (formerly Geological Survey of Greenland).

Cambrian platform margin and outer shelf deposits in North Greenland are best known from the extensive southern outcrop belt along the northern margin of the Inland Ice (Fig. 1; see Ineson \& Peel, 1987; Surlyk \& 


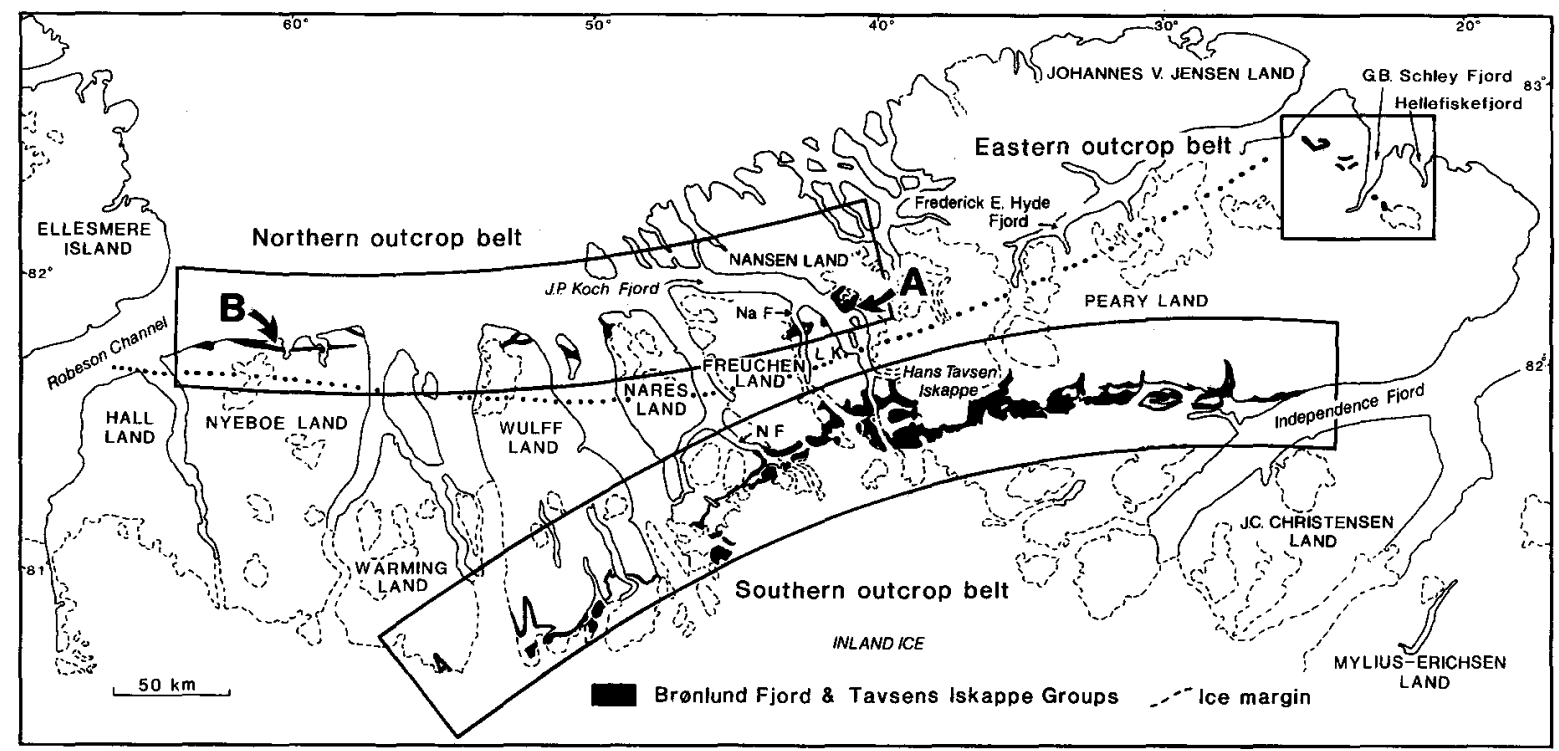

Fig. 1. Sketch map showing the distribution of the Brønlund Fjord and Tavsens Iskappe Groups in North Greenland. These strata crop out in three discrete areas: the southern, eastern and northern outcrop belts. The dotted line marks the position of the Navarana Fjord lineament. A and B show the location of the sections in Fig. 5 (see also Fig. 12). LK, Lauge Koch Land; NaF, Navarana Fjord; NF, Nordenskiöld Fjord. Localities in north Nyeboe Land shown in Fig. 7.

Ineson, 1987; Higgins et al.; 1991a, b). However, contemporaneous strata also crop out in an east-west belt parallel to the northern coastline of western and central North Greenland (Fig. 1), in the cores of a series of open to tight anticlinal folds and in thrust slices (Higgins \& Soper, 1985; Higgins et al., 1992). The sediments exposed in this outcrop belt were deposited on the deeperwater, more distal portion of the Cambrian shelf, near the transition to the basin slope. With the exception of the northernmost, allochthonous sections, these strata are readily assigned to the Brønlund Fjord and Tavsens Iskappe Groups as defined from the southern outcrop belt (Peel, 1979a; Ineson \& Peel, 1980; Ineson, 1988; Ineson \& Peel, unpublished).

The aim of this paper is to present a review of the stratigraphy and regional depositional setting of the Brønlund Fjord and Tavsens Iskappe Groups in their northern outcrop to act as an introduction to the detailed taxonomic and biostratigraphic studies that follow in this volume (Babcock, 1994a, b; Robison, 1994; Peel, 1994). In addition, the Kap Stanton Formation, a new formation of the Tavsens Iskappe Group, is formally defined. In particular, the aim is to clarify the relationship between these northern sections and the better known, more proximal shelf sediments of the southern outcrop belt (Fig. 1).

\section{Regional setting}

During the early Palaeozoic, North Greenland formed part of the Franklinian Basin which extended westwards into Arctic Canada. In Greenland, the preserved basin fill stretches almost $1000 \mathrm{~km}$ from east to west and $200 \mathrm{~km}$ from north to south. The succession is about $8 \mathrm{~km}$ thick and is essentially of early Palaeozoic age, although possibly extending down into the latest Proterozoic and up into the earliest Devonian.

The outcrop pattern of the Lower Palaeozoic broadly parallels the east-west coastline of North Greenland. Archaean crystalline basement and overlying Proterozoic sedimentary strata crop out along the fringes of the Inland Ice in the south and east. Succeeding Lower Palaeozoic strata occupy most of the remaining ice-free terrain. Outliers of Late Palaeozoic and Mesozoic age unconformably overlie the Franklinian Basin strata in eastern areas of North Greenland (see Stemmerik \& Håkansson, 1991, Håkansson et al., 1991). Rocks of the Franklinian Basin are largely undeformed in the south; the degree of deformation increases northwards and the metamorphic grade is amphibolite facies in northernmost North Greenland; details of the structure and metamorphic history are given in Higgins et al. (1985) and Soper \& Higgins (1990).

The full evolutionary history of the Franklinian Basin in North Greenland is given in some detail in recent review articles (Higgins et al., 1991a, b); a brief description is given here with emphasis on the Cambrian shelf. 
For much of the early Palaeozoic, the basin consisted of two discrete depositional elements: a shelf to the south, bordering the craton, passing northwards into a deepwater trough. The position and nature of the transition from shelf to trough varied during the early Palaeozoic (Hurst \& Surlyk, 1983; Surlyk \& Hurst, 1983, 1984). In certain periods (e.g. Early Cambrian, Late Ordovician Early Silurian), the entire shelf region was the site of shallow-water carbonate sedimentation and the shelf-totrough transition was an abrupt, often precipitous scarp (see Surlyk \& Ineson, 1987, 1992; Peel et al., 1992). At other times (e.g. late Early Cambrian), the shelf was dominated by siliciclastic sediments and showed a typical continental shelf profile with a shelf-slope break in several hundred metres of water. Intermediate profiles were also represented, for example from the late Early Cambrian to the earliest Ordovician, during which time a shallow-water carbonate platform occupied the southern inner region of the shelf, grading northwards onto the mixed carbonate-siliciclastic outer shelf which in turn passed abruptly into the deep-water trough.

The position of the shelf-to-trough transition follows a number of roughly east-west lineaments. These features probably represent deep-seated faults or monoclines which became successively active during the early Palaeozoic resulting in backstepping of the shelf margin. Thus, from the earliest Cambrian to the Early Ordovician, the shelf margin followed a line from Frederick E. Hyde Fjord through outer J. P. Koch Fjord and north of the present Wulff Land - Nyeboe Land coastline (Fig. 1). In the Early Ordovician, the margin shifted southwards to the Navarana Fjord lineament which proceeded to control the position of the carbonate platform margin until the late Llandovery. At this time, the outer platform foundered and basinal sediments progressively onlapped the shelf, with ultimate drowning of the preserved shelf at the Llandovery-Wenlock boundary. Deep-water sedimentation continued over North Greenland until at least the

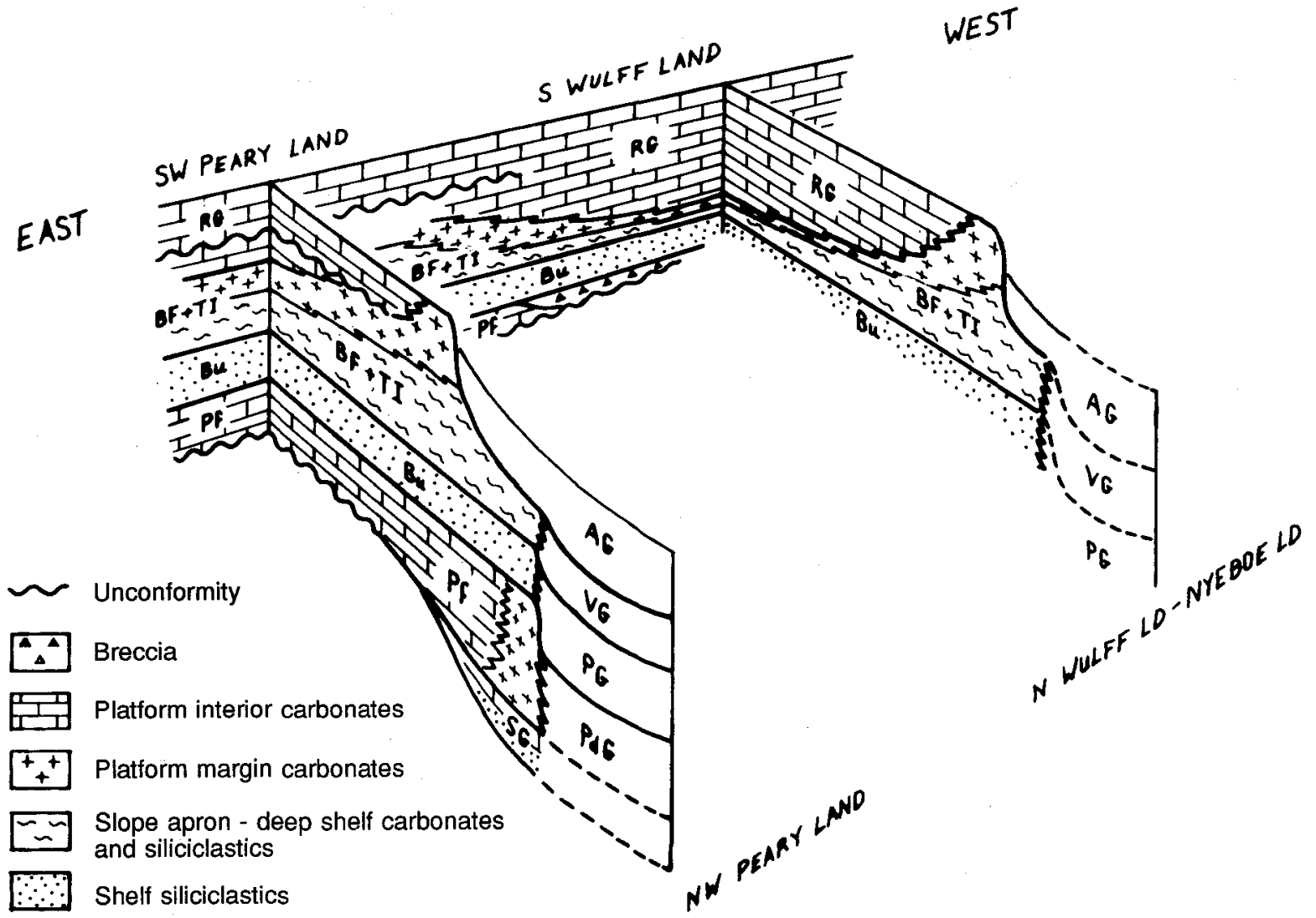

Fig. 2. Fence diagram (view from north) showing the regional stratigraphy of the Cambrian shelf and deep-water trough. SG, Skagen Group; Pf, Portfjeld Formation; PdG, Paradisfjeld Group; Bu, Buen Formation; PG, Polkorridoren Group; BF, Brønlund Fjord Group; TI, Tavsens Iskappe Group; RG, Ryder Gletscher Group; VG, Vølvedal Group; AG, Amundsen Land Group. 
latest Silurian; the Franklinian Basin was uplifted and deformed in the mid-Palaeozoic Ellesmerian orogeny.

\section{Stratigraphic framework and shelf evolution}

The Cambrian sedimentation history of the North Greenland shelf from Peary Land in the east to Nyeboe Land in the west (Fig. 1) is recorded by the Skagen Group (?lowermost Cambrian), the Portfjeld and Buen Formations (Lower Cambrian) and the Brønlund Fjord, Tavsens Iskappe and Ryder Gletscher Groups (Lower-Upper Cambrian; Fig. 2). In recent reviews (Higgins et al., 1991a, b), Cambrian shelf evolution has been considered in terms of four stages.

The mixed carbonate-siliciclastic Skagen Group, representing Stage 1 of Higgins et al. (1991a, b) is recognised in isolated exposures from north-east Peary Land, in the east, to northern Wulff Land, in the west (Figs 1, 2 ); it records deposition on a storm-dominated shelf following the initial transgression of Proterozoic basement. The succeeding Portfjeld Formation (Stage 2), however, extends widely over central areas of North Greenland and records the development of a shallow-water carbonate platform over much of the Franklinian shelf in North Greenland (Fig. 3). At the northern limit of the shelf, the platform was fringed by a belt of carbonate sands and stromatolitic mounds, deposited under turbulent, energetic conditions; the margin was a steep escarpment, at least in its latter stages (Higgins et al., 1991a; Peel et al., 1992).

Following exposure and karstification of the platform, the shelf was transgressed; the siliciclastic shelf strata deposited during this episode (Stage 3; Fig. 3) are assigned to the Buen Formation which is recognised throughout central and east North Greenland and can be correlated with similar siliciclastic formations in westernmost North Greenland.

The mud-dominated deep shelf strata of the upper Buen Formation are succeeded abruptly by carbonates of late Early Cambrian age; this boundary heralds the development of a major early Palaeozoic carbonate platform that ultimately decked the entire Franklinian shelf and may have been connected with the East Greenland carbonate platform on the Iapetus margin of Laurentia. During the early phases of its development (Stage 4), however, the shallow-water platform was restricted to the southern, inner portion of the shelf and passed northwards into a deeper-water outer shelf setting (Fig. 3). The deep shelf, in turn, graded northwards into the deep-water trough. The precise nature of the shelf-to-trough transition at this time is unknown. Although demonstrably a steep scarp with considerable relief during the latter part of Stage 2 and early Stage 3 (upper Portfjeld and lower
Buen Formations, see above), differential subsidence across this structural lineament may have been less important and the transition more subdued by latest Early Cambrian times. The contrast in thickness between the outermost shelf deposits and the basinal Vølvedal Group, however, indicates that significant relief persisted at this margin throughout the Cambrian and into the Ordovician (see Friderichsen et al., 1982; Higgins et al., 1991a, b, 1992).

The fundamental subdivision of the shelf environment during the Cambrian is reflected in the stratigraphic scheme (Fig. 2): platform interior rocks are assigned to the Ryder Gletscher Group whereas platform margin, carbonate slope apron and deep shelf strata are assigned to the Brønlund Fjord and Tavsens Iskappe Groups. The deeper-water outer shelf sediments grade southwards and up-section into platform margin and platform interior facies reflecting a general northward progradation of the platform during the Cambrian (Fig. 2).

This simple south to north progradational pattern, however, does not explain the east-west variation in the Cambrian stratigraphy (see Figs 2, 4). In western and much of central North Greenland, the shelf subsided uniformly from the Early Cambrian to the Early Silurian, accumulating a thick and essentially conformable succession of platform carbonates. In contrast, the eastern margin of the North Greenland craton experienced uplift during the Middle and Late Cambrian, probably in response to an early collisional event along the western margin of the Iapetus Ocean (Surlyk \& Hurst, 1984; Surlyk, 1991). This resulted in progressive exposure of eastern shelf areas during the Cambrian and the development of a regional unconformity at the base of the Wandel Valley Formation (uppermost Lower-Middle Ordovician; Fig. 2). Uplift was greatest in magnitude and duration in the east so that the hiatus decreases in stratigraphic importance westwards and is not recognised farther west than Nares Land (Figs 1, 2).

Thus, in the southern outcrop belt (Fig. 1), the Brønlund Fjord, Tavsens Iskappe and Ryder Gletcher Groups record northward progradation of shallow-water carbonate sediments over outer shelf deposits. In eastern areas, the platform became progressively emergent during the Cambrian and platform interior facies (i.e. Ryder Gletscher Group) are only locally preserved beneath the Wandel Valley Formation basal unconformity (Fig. 2). In western North Greenland and adjacent areas of central North Greenland, however, the outer shelf, slope apron and platform margin deposits of the Brønlund Fjord Group, and by inference the Tavsens Iskappe Group, are conformably succeeded by Cambro-Ordovician platform carbonates assigned to the Ryder Gletscher Group (Fig. 2). 
Early Cambrian

(Stage 2)

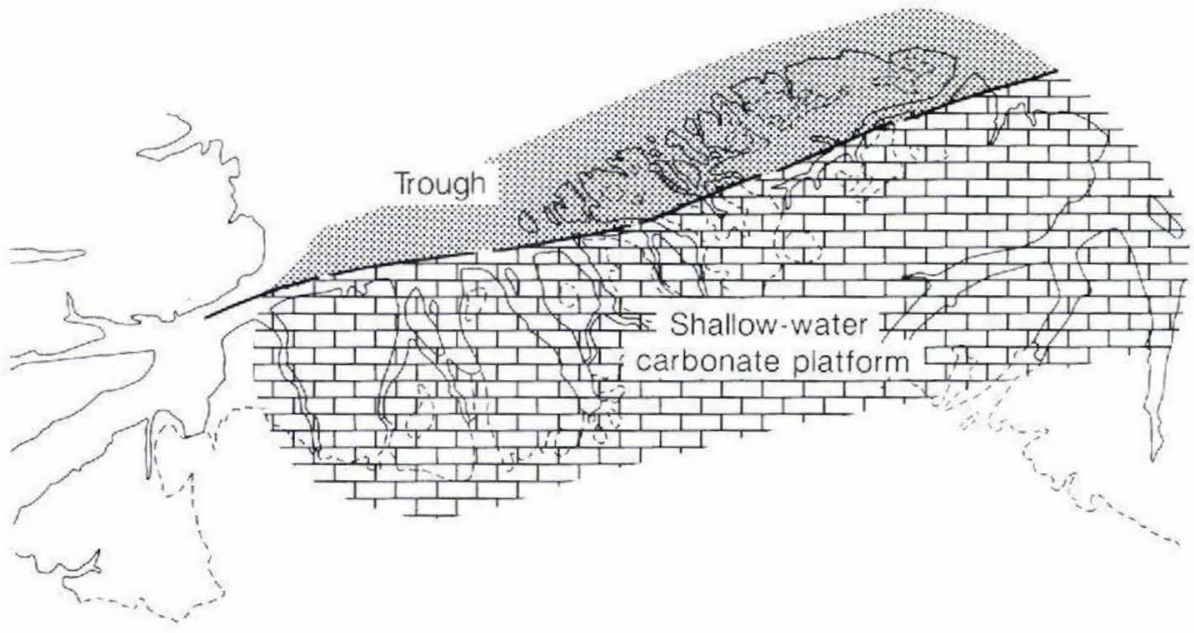

Early Cambrian

(Stage 3)

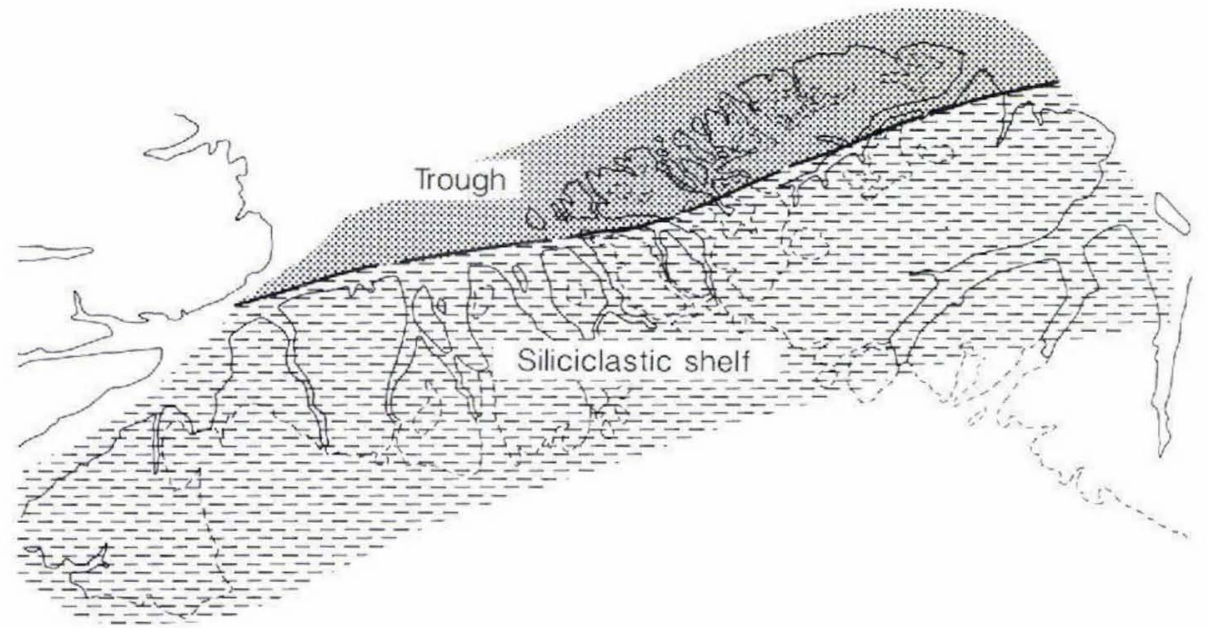

late Early - Middle Cambrian

(early Stage 4)

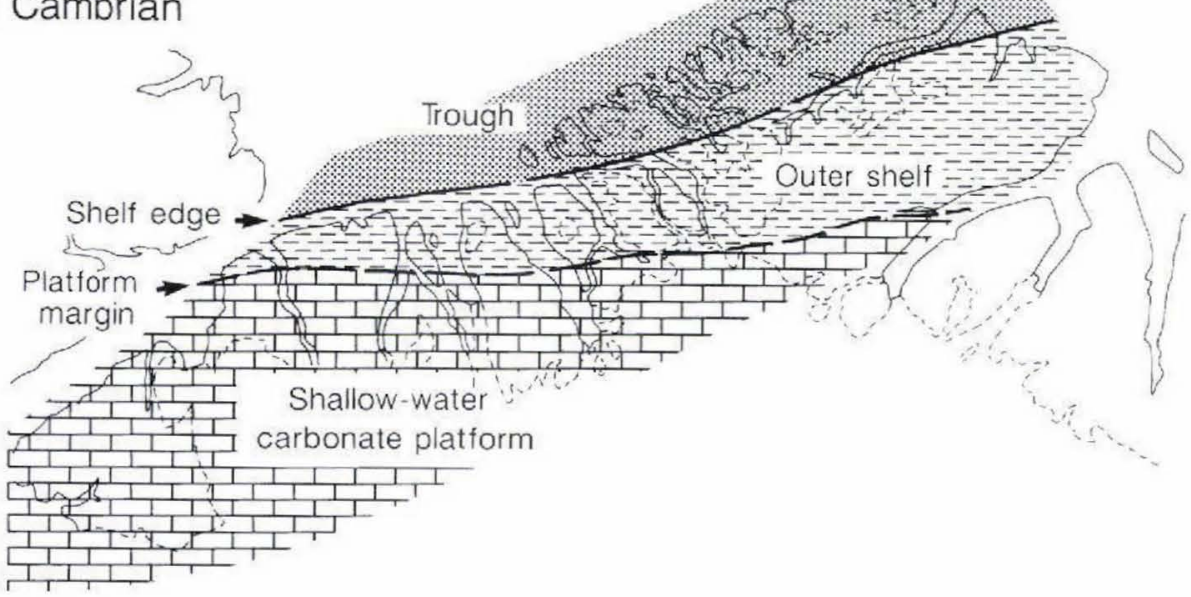

Fig. 3. Cambrian palaeogeography of North Greenland; see text for discussion. The position of the Cambrian shelf edge is extrapolated westwards from the exposed margin of the Portfjeld Formation platform (Stage 2) in north-west Peary Land; the inferred basin slope deposits (Stages 3, 4) occurring in thrust slices along the northern coastlines of Nares Land, Wulff Land and Nyeboe Land (see Higgins et al., 1992) are not incorporated in this simplified reconstruction. 


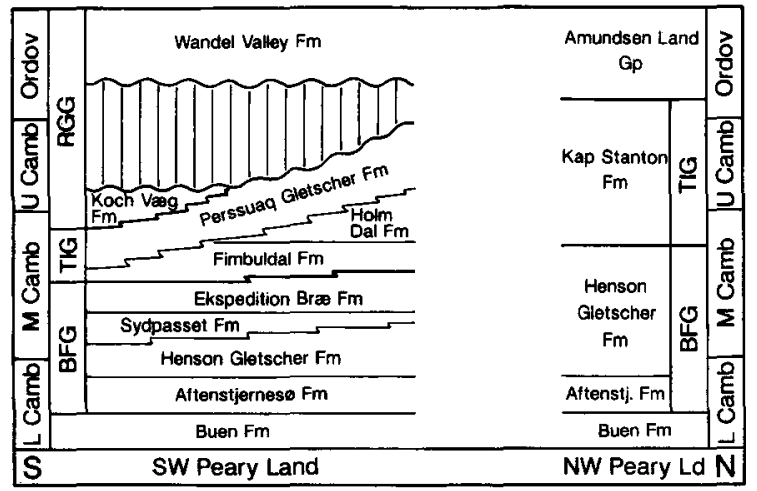

b

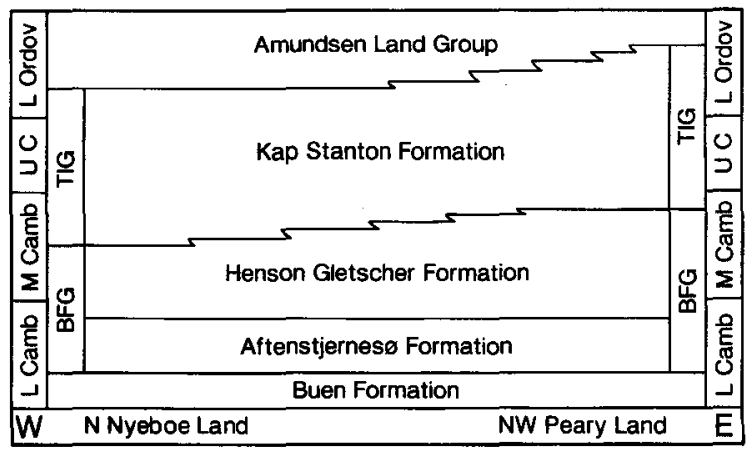

Fig. 4. Lithostratigraphy of the Brønlund Fjord (BFG) and Tavsens Iskappe Groups (TIG) in (a) a south-to-north transect in west Peary Land and (b) a west-to-east transect in the northern outcrop belt (see Fig. 1). RGG, Ryder Gletscher Group.

In the northern outcrop belt from outer J. P. Koch Fjord to northern Nyeboe Land (Fig. 1), the carbonate slope apron and deep, outer shelf sediments of the Brønlund Fjord and Tavsens Iskappe Groups were deposited basinward of the maximum northernmost extent of the platform (Fig. 2). They are overlain by black, cherty, graptolitic mudstones of Early Ordovician age, reflecting a shift in the position of the trough margin in the Early Ordovician from north of the northern coastline of central areas of North Greenland to the Navarana Fjord lineament (Figs 1, 2, 3). The easternmost sections of the northern outcrop belt, in Navarana Fjord and outer J. P. Koch Fjord, can be readily correlated with the southern outcrop belt since the transition from platform to outer shelf is superbly exposed in these southern exposures (see Ineson \& Peel, 1980, 1987; Higgins et al., 1991a, b). West of Nordenskiöld Fjord (Fig. 1), however, this transition is not exposed; platform carbonates dominate the southern outcrop and outer shelf facies make up the northern outcrop belt, the intervening margin being bur- ied beneath younger strata. The evolution of the platform margin in this western area is discussed further below.

\section{Lithostratigraphy}

Three formations are assigned to the Brønlund Fjord and Tavsens Iskappe Groups in the northern outcrop belt; these are equivalent to the lower three units of the four part Cambrian - Lower Silurian starved basin sequence described by Higgins \& Soper (1985). The lower two formations, overlying the Buen Formation (Figs 2, 4), are assigned to the Aftenstjernes $\emptyset$ and Henson Gletscher Formations of the Brønlund Fjord Group, as defined from the southern outcrop belt (Ineson \& Peel, unpublished; see also Higgins et al., 1991a, b). The third formation is defined here as the Kap Stanton Formation, a new formation of the Tavsens Iskappe Group; this formation is succeeded by the Amundsen Land Group, defined from a more basinal setting by Friderichsen et al. (1982). Detailed stratigraphic data from this Cambrian-Ordovician outcrop belt were recently presented by Higgins $e t$ al. (1992). Brief descriptions of the typical facies of the respective formations are included here, together with an interpretation of the broad depositional setting.

\section{Brønlund Fjord Group}

\section{Aftenstjernes $\emptyset$ Formation}

Description. At the type section in southern Lauge Koch Land (Fig. 1; Ineson \& Peel, unpublished), the Aftenstjernesø Formation comprises $c .62 \mathrm{~m}$ of dolomites that include glauconitic, phosphoritic grainstones and packstones, carbonate turbidites, nodular and laminated dolomites and carbonate breccia beds. In its northern outcrop, from outer J. P. Koch Fjord, western Peary Land to northern Nyeboe Land (Fig. 1), the Aftenstjernes $\emptyset$ Formation is typically $25-50 \mathrm{~m}$ thick (Figs 5,6 ), although anomalously thick sections have been recorded locally (e.g. $c$. $80 \mathrm{~m}$ in north-east Nyeboe Land; Higgins et al., 1992). In north-south transects, the formation thins slightly northwards (see Higgins et al., 1992, fig. 4).

The base of the formation is typically sharp and is marked by a thin rusty-weathering interval of pyritic, phosphoritic dolomitic limestones that include nodular mudstones and wackestones and skeletal, intraclastic packstones and grainstones. This unit, which is equivalent to 'Member A' of the Aftenstjernes $\varnothing$ Formation in its southern outcrop (see Frykman, 1980), forms a readily recognisable marker bed, about $1 \mathrm{~m}$ thick, in eastern sections (Fig. 6a) above the dark greenish-grey siliciclastic mudstones of the Buen Formation. In western sections, this unit may be thicker and the boundary more 
a

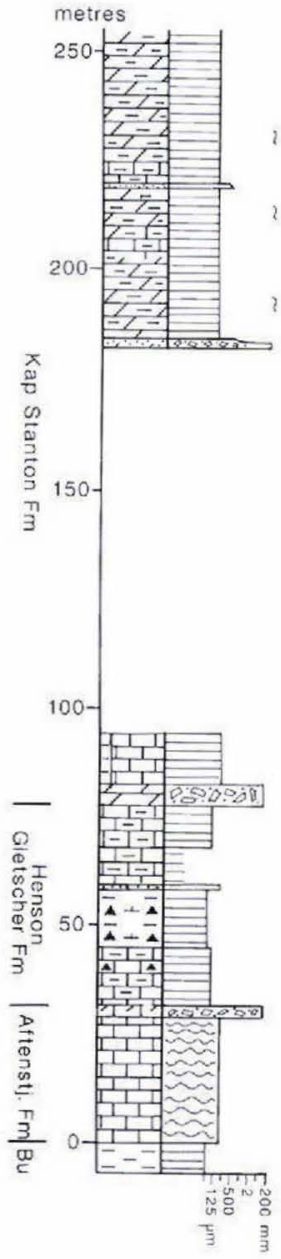

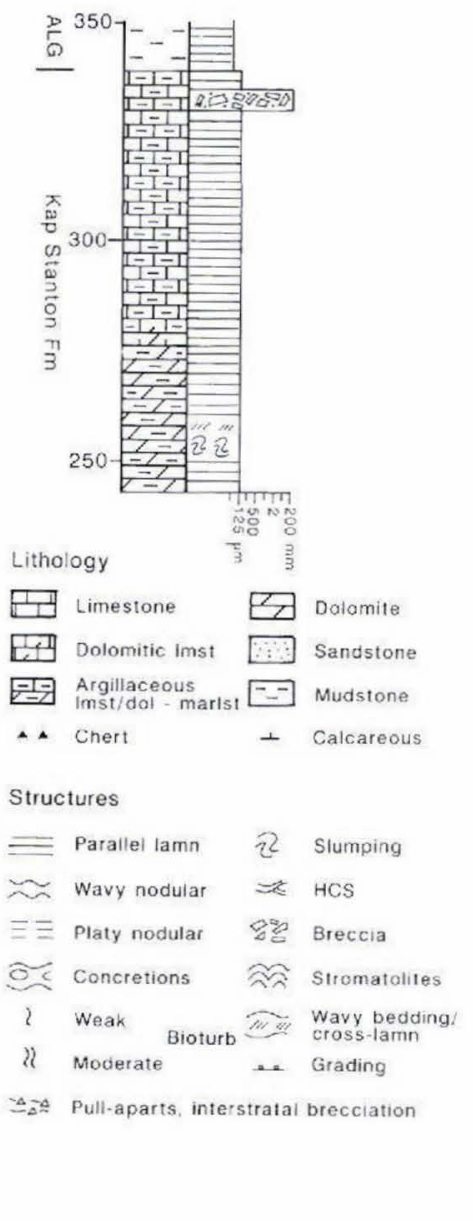

b

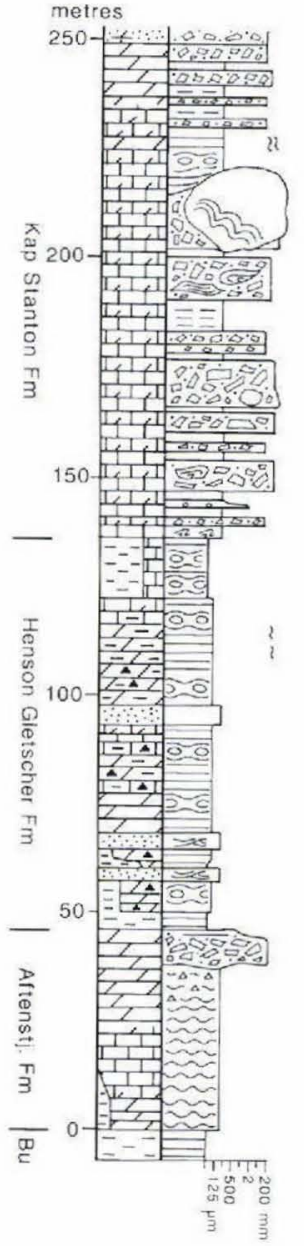

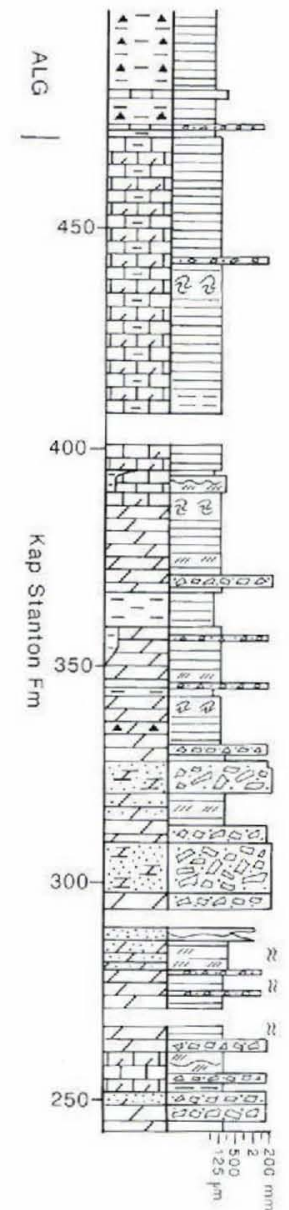

Fig. 5. Stratigraphic sections through the Brønlund Fjord and Tavsens 1skappe groups in the northern outcrop belt. a, outer J. P. Koch Fjord; b, Hand Bugt, northern Nyeboe Land (see Fig. 1). The legend also applies to Fig. 8. Bu, Buen Formation; Aftenstj., Aftenstjernesø; ALG, Amundsen Land Group.

gradational in character (see Fig. 5b). Above this basal marker, the formation is dominated by nodular, thinbedded, argillaceous, dark grey or black lime mudstones or dolomites. Parallel lamination is commonly evident and cross-lamination is observed locally in rare graded limestone beds. The formation is capped by a highly persistent, clast-supported carbonate breccia bed, up to $20 \mathrm{~m}$ thick, which forms a characteristic marker bed throughout the northern outcrop of the Aftenstjernes $\emptyset$ Formation (Figs 5, 6; Higgins et al., 1992). A closely comparable and probably correlative mass-flow breccia bed caps the Aftenstjernes $\varnothing$ Formation over much of the southern outcrop belt (see Ineson, 1980, 1985; Ineson \& Peel, unpublished).

Boundaries and age. The carbonate-dominated Aftenst- jernesø Formation conformably overlies fine-grained siliciclastics of the Buen Formation as in the southern outcrop belt (Ineson \& Peel, 1980; unpublished); the boundary is marked by a distinctive pyritic, phosphoritic horizon or interval (see Fig. 6). The top of the formation is defined at the top of a laterally persistent carbonate mass-flow breccia sheet that marks a shift from the carbonate-dominated Aftenstjernes $\varnothing$ Formation to the black cherty calcareous mudstones and argillaceous lime mudstones of the Henson Gletscher Formation.

In its southern outcrop, the Aftenstjernesø Formation is assigned a late Early Cambrian age; the basal beds yield a diverse fauna indicative of the Bonnia-Olenellus Zone (Palmer \& Peel, 1979; Bendix-Almgreen \& Peel, 1988). Similarly, in the northern outcrop belt, fossils are generally only present in the lowermost beds which have 
Fig. 6a. Aftenstjernes $\emptyset$ Formation (A) overlying the poorly exposed Buen Formation (B). Note the lightcoloured scree emanating from the base of the Aftenstjernes $\emptyset$ Formation; this reflects the presence of the distinctive pyritic marker bed at the base of the formation. Note also the massive carbonate breccia bed (c. 7 $\mathrm{m}$ thick) capping the formation. East side of Navarana Fjord.

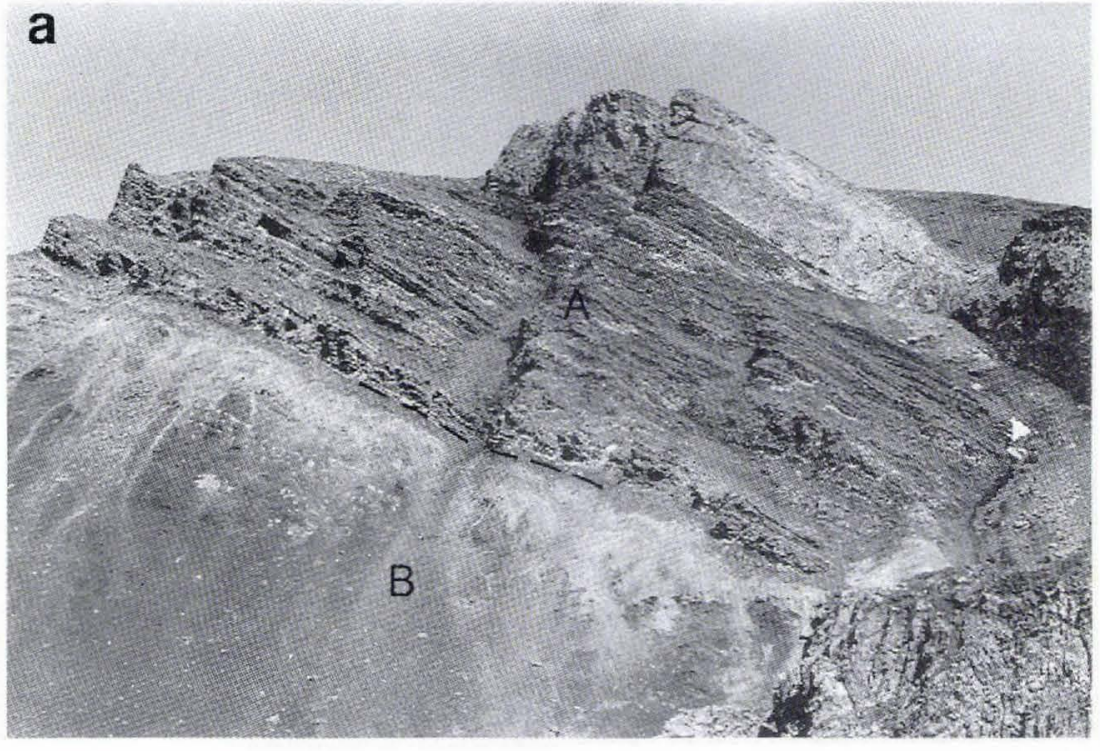

Fig. 6b. Dark-coloured Cambrian and Ordovician strata capped by pale sandstone turbidites of the Lower Silurian Merqujôq Formation (M). B, Buen Formation (Lower Cambrian); A, Aftenstjernesø Formation (Lower Cambrian); HG, Henson Gletscher Formation (Lower-Middle Cambrian); KS, Kap Stanton Formation (Middle Cambrian - Ordovician); AL, Amundsen Land Group (Ordovician); D, Tertiary dyke. East side of Navarana Fjord. Aftenstjernesø Formation is c. $30 \mathrm{~m}$ thick.

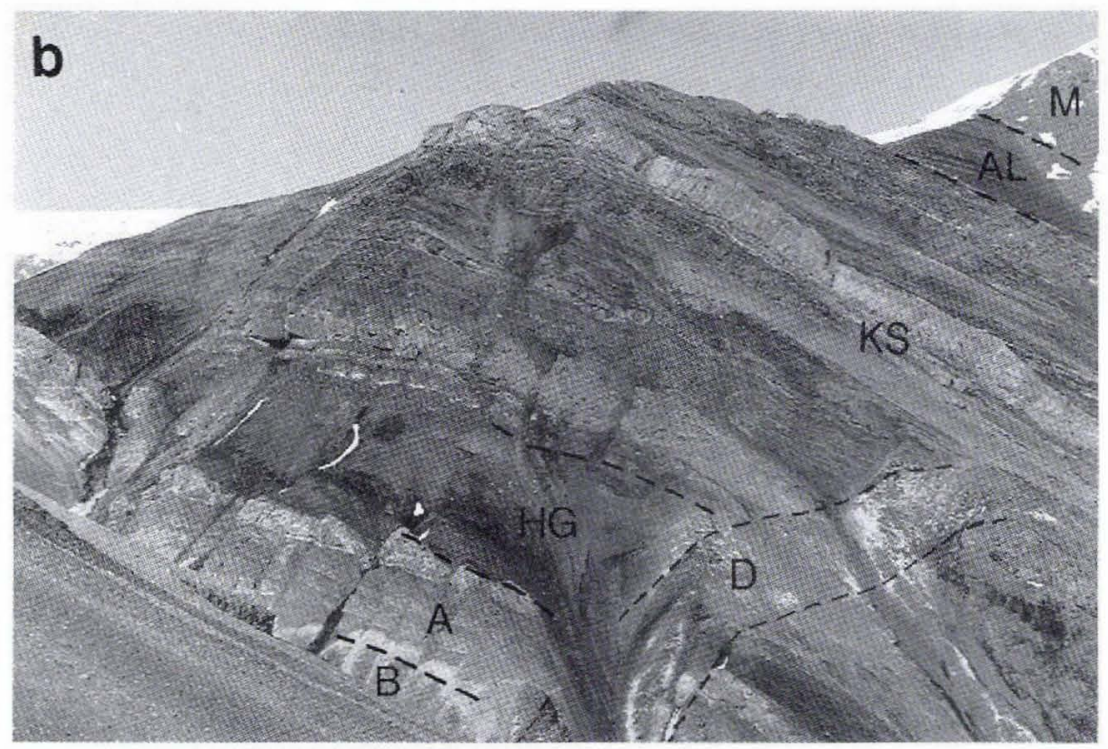

yielded the coeloscleritophoran Chancelloria and hyolithids at a number of localities. An atypically thick section in north-east Nyeboe Land, however, is richly fossiliferous throughout the formation. The fauna includes olenellid and eodiscid trilobites, associated with the helcionelloid mollusc Latouchella, dermal sclerites of the palaeoscolecidan worm Hadimopanella and inarticulate brachiopods (Peel, 1974, 1979b; Dawes \& Peel, 1984; Peel \& Larsen, 1984; Higgins et al., 1992). Blaker (1991) described Serrodiscus speciosus (Foord, 1873) [= S. bellimarginatus of Dawes, 1976, p. 277 and Peel, 1979b, p. 116], together with S. daedalus Öpik, 1975, S.? latus Rasetti, 1966 and Olenellus sp. A late Early Cambrian age is indicated and the boundaries of the Aftenst- jernesø Formation are considered to be essentially isochronous throughout both the northern and southern outcrop areas.

Facies and depositional environment. The dominant facies, comprising thin-bedded, nodular, argillaceous lime mudstones, typically shows parallel lamination and was deposited largely out of suspension, both from the water column and from starved muddy turbidites. Bioturbation is rare, indicating poorly-oxygenated bottom conditions. Rare thin graded, cross-laminated packstones and wackestones record the episodic incursion of more energetic turbidity currents bearing carbonate sand and silt. The thick, clast-supported, unstratified carbonate breccia bed 
capping the formation has a dolomitised carbonate mud matrix, indicating deposition from a viscous debris flow (see Ineson, 1980, 1988).

The Aftenstjernes $\varnothing$ Formation in the northern outcrop belt records deposition primarily of hemipelagic lime mud in an oxygen-starved, sub-wavebase, low energy environment. The scarcity of sand-grade turbidites and coarse debris flow deposits indicates deposition in a distal, outer shelf setting beyond the depositional range of much of the coarser sediment gravity flows derived from the advancing platform and slope apron (see Ineson, 1980, 1985; Higgins et al. 1991a, b).

\section{Henson Gletscher Formation}

Description. The Henson Gletscher Formation forms a dark grey or black, recessive-weathering interval sandwiched between the more resistant carbonates of the Aftenstjernesø and Kap Stanton Formations (Figs 5, 6b). It is commonly between $20 \mathrm{~m}$ and $60 \mathrm{~m}$ thick but attains some $90 \mathrm{~m}$ in northern Nyeboe Land (Fig. 5b).

In its southern outcrop, the Henson Gletscher Formation is characterised by dark, organic-rich argillaceous lime mudstones and dolomites with a distinctive sandstone unit in the middle of the formation that thickens southwards (Ineson \& Peel, 1980, 1987, unpublished; Christiansen et al., 1987). In the northern outcrop belt, the formation is carbonate-starved relative to the southern succession, being composed mainly of black, calcareous or dolomitic, shaly mudstones and black cherts with subordinate spicular argillaceous lime mudstones or dolomites. The proportion of carbonate increases westwards and the Henson Gletscher Formation in northern Nyeboe Land (Fig. 5b) is strongly reminiscent of the type section in Lauge Koch Land (see fig. 22 in Ineson, 1980). At Hand Bugt (Fig. 5b), thin beds and laminae of skeletal packstone occur at certain levels in the upper half of the formation (see Babcock, 1994a, b).

Sandstones are present in many sections through the Henson Gletscher Formation in the northern outcrop belt but are best developed in northern Wulff Land and Nyeboe Land (Fig. 5b). These white, pale grey or yellow sandstones are very fine-grained to fine-grained; beds are typically $20-80 \mathrm{~cm}$ thick and the sandstones characteristically form discrete 3-4 m thick units interbedded with dark carbonates or cherty mudstones (Fig. 5b). Individual sandstone beds are sheet-like over a few tens of metres but often pinch and swell. They are internally structureless or show sub-parallel or gently undulating lamination. Dish structures were observed locally and hummocky cross-stratification was identified in northern Nyeboe Land (Fig. 5b).
Boundaries and age. The Henson Gletscher Formation conformably overlies the Aftenstjernes $\emptyset$ Formation (Figs 5,6 ); the boundary is sharp although locally irregular and is placed where black, cherty shaly carbonates or mudstones overlie the prominent carbonate breccia bed at the top of the Aftenstjernes $\varnothing$ Formation (Fig. 6a). The top of the formation is placed where the recessive-weathering dark carbonates and mudstones are succeeded by a more prominent, yellow-brown weathering carbonate-dominated succession assigned to the Kap Stanton Formation (Fig. 6b). The basal beds of the latter formation commonly consist of thin-bedded, nodular lime mudstones or dolomites or, at a number of localities, the base is marked by a carbonate breccia bed (Fig. 5a).

The formation is typically poorly fossiliferous in eastern sections in the northern outcrop belt; indeterminate agnostoid trilobites were collected from the upper third of the formation in outer J. P. Koch Fjord (Fig. 5a; locality 3 in fig. 1 of Babcock, 1994a, b and Robison, 1994). The overlying Kap Stanton Formation yielded rich latest Middle Cambrian faunas (Lejopyge laevigata Zone) at this locality, some $10-20 \mathrm{~m}$ above the top of the Henson Gletscher Formation (see Babcock, 1994a, b; Robison, 1994), suggesting that the uppermost beds of the formation are of late Middle Cambrian age in these eastern sections.

In northern Nyeboe Land, in the west, rich trilobite faunas were collected from a number of levels in the Henson Gletscher Formation (locality 1, fig. 1 of Babcock, 1994a, b and Robison, 1994). These faunas, which are reported in detail in this volume (see Babcock, 1994a, b; Robison, 1994; Peel, 1994), occur within the upper two-thirds of the formation. The lower third of the formation is unfossiliferous but is probably of late Early Cambrian age, by analogy with the Henson Gletscher Formation in the southern outcrop belt (Ineson \& Peel, unpublished).

The lowest of the faunas in the Hand Bugt section occurs at $88 \mathrm{~m}$ in the section, some $5 \mathrm{~m}$ below the uppermost sandstone bench (Fig. 5b); this fauna is indicative of an early Middle Cambrian age (Glossopleura Zone; Babcock, 1994a). In addition to polymeroid trilobites, this horizon has also yielded the helcionelloid mollusc Latouchella arguta (Resser, 1939), originally described from the lower Middle Cambrian of the Wasatch Mountains (Resser, 1939).

Succeeding collections, at $102 \mathrm{~m}$ and $117-119 \mathrm{~m}$ indicate respectively the Ptychagnostus gibbus and $P$. atavus Zones of the medial Middle Cambrian (Babcock, 1994a; Robison, 1994). At 102 m, a diverse trilobite fauna is accompanied by elkaniid and acrotretid brachiopods (Lars E. Holmer, personal communication, 1993) and the mollusc Pelagiella. In an accompanying paper, 


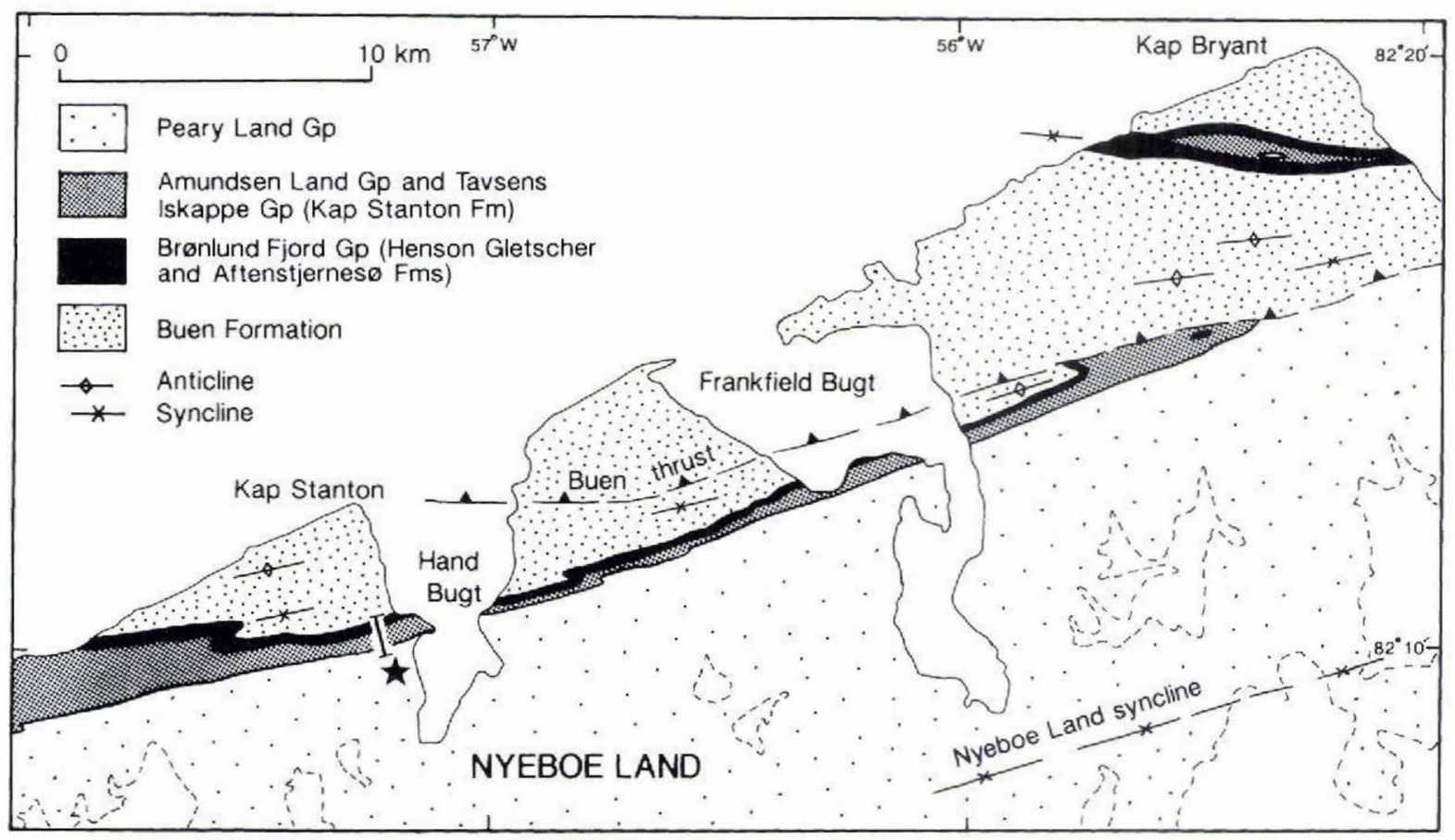

Fig. 7. Sketch map of Hand Bugt, northern Nyeboe Land, showing the location (star) of the type section of the Kap Stanton Formation.

Peel (1994) describes the enigmatic Nyeboeconus robisoni gen. et sp. nov. from this horizon. It should be noted that in the southern outcrop belt, the sandstone-dominated interval in the middle of the Henson Gletscher Formation is thought to be wholly of Early Cambrian age; Bonnia-Olenellus faunas were recorded from beneath, within and locally immediately above the sandstone interval whereas Middle Cambrian ( $P$. gibbus Zone) faunas first appear some 5-10 $\mathrm{m}$ above the top of the sandstone unit. Early Middle Cambrian (Glossopleura Zone) faunas, however, have not been located in the southern outcrop belt.

Late Middle Cambrian faunas were not recorded from the Henson Gletscher Formation in these western sections, suggesting that the boundary between the Henson Gletscher and Kap Stanton Formations is markedly diachronous in this outcrop belt, younging eastwards. This may reflect the oblique nature of the section through the deep shelf facies belts provided by the northern outcrop belt, such that the western sections record a more proximal setting relative to the platform than the eastern sections (see discussion below).

The marked diachroneity of the top of the Henson Gletscher Formation passing away from the platform is illustrated further by comparing the type section in the southern outcrop belt at the head of J. P. Koch Fjord with the section to the north (locality 3 in fig. 1 of Babcock, 1994a, b and Robison, 1994) in the outer stretches of the fjord (Figs 1, 5a). The boundary falls in the $P$. gibbus Zone of the medial Middle Cambrian in the former section and is of latest Middle Cambrian age ( $L$. laevigata Zone) in the latter. The successive northward pinchout of carbonate slope apron wedges leads to the amalgamation of dark, argillaceous, carbonate-starved deep shelf successions which are assigned en masse to the Henson Gletscher Formation (Fig. 4a).

Facies and depositional environment. The Henson Gletscher Formation is a recessive-weathering, carbonate-starved succession in relation to the Aftenstjernes $\emptyset$ Formation beneath and the Kap Stanton Formation above. It is dominated by black shaly mudstones and variably dolomitised marlstones and argillaceous lime mudstones. These facies show well-developed parallel lamination, often defined by variation in carbonate or silt content; carbonate concretions are common. Laminae and thin beds of skeletal packstone occur at certain levels. Black chert forms discrete beds and nodules, and sponge spicules are common. Bioturbation is very rare. This facies represents deposition of clay and subordinate lime mud primarily from suspension; the thin coarser beds and laminae probably represent deposition from dilute turbidity currents or possibly storm currents. The well-sorted, fine-grained sandstone sheets have sharp, locally erosive 
bases and, although typically structureless, may show dish structures, diffuse parallel stratification and hummocky cross-stratification; deposition was from bottomhugging sandy density currents probably initiated by storms.

Deposition of the Henson Gletscher Formation in the northern outcrop belt occurred in a low-energy sub-wavebase environment in a carbonate-starved outer shelf setting. The high organic content, parallel-lamination and scarcity of bioturbation indicates oxygen-deficient bottom conditions. An influx of siliciclastic sand into the outer shelf environment occurred at around the EarlyMiddle Cambrian boundary.

Fig. 8. Type section of the Kap Stanton Formation, northern Nyeboe Land (see Fig. 7). Note the overall decrease in thickness and abundance of carbonate breccia beds up-section.

\section{Tavsens Iskappe Group}

\section{Kap Stanton Formation}

(new formation)

History. The formation has been previously referred to as the 'dolomite unit', the third of four units making up the 'Cambrian - Lower Silurian starved basin sequence' (Higgins \& Soper, 1985). The lower two of these units are assigned to the Aftenstjernes $\emptyset$ Formation and Henson Gletscher Formation as described above; the fourth, uppermost unit is assigned to the Amundsen Land Group of Friderichsen et al. (1982).

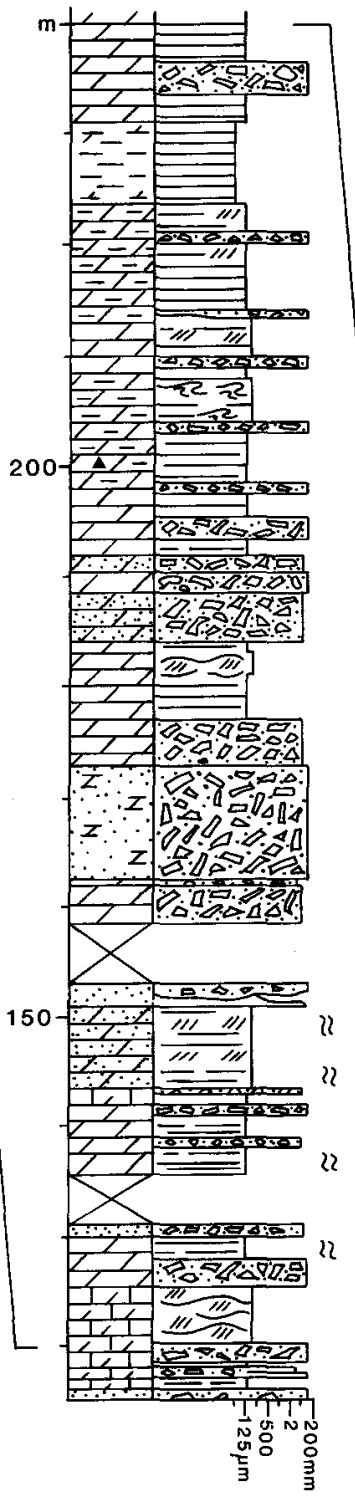




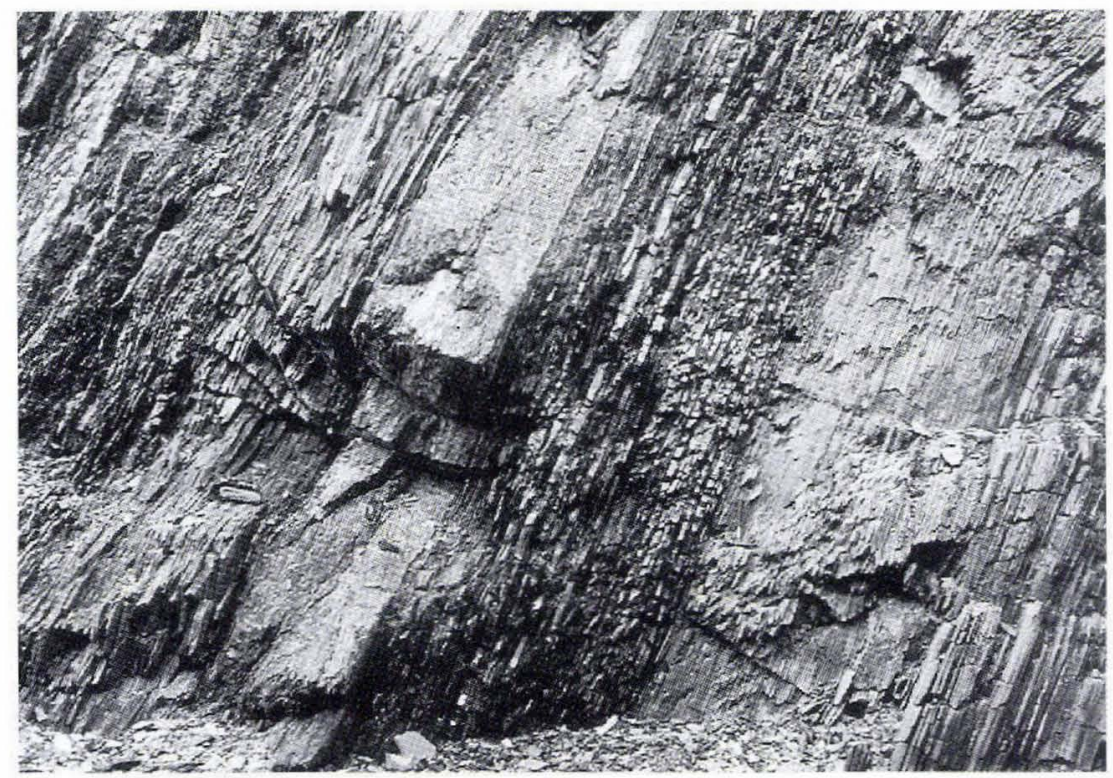

Fig. 9. Overturned thinly-bedded argillaceous lime mudstones; Kap Stanton Formation, type section ( $c$. $250 \mathrm{~m}$ above base), northern Nyeboe Land. Massive slump-breccia bed (centre left) is about $1 \mathrm{~m}$ thick.

Name. After Kap Stanton, a prominent cape in northern Nyeboe Land (Fig. 7).

Type section. The type section (Fig. 8) is located c. $2 \mathrm{~km}$ west of Hand Bugt on the north coast of Nyeboe Land (Figs 1, 7). The steeply dipping, overturned strata are exposed on the east side of a small stream gully on the ridge overlooking the west shore of Hand Bugt. This is locality 1 of Babcock (1994a, b) and Robison (1994).

Thickness. The formation is about $350 \mathrm{~m}$ thick at the type section. It varies in thickness from c. $100 \mathrm{~m}$ in northern Wulff Land and Lauge Koch Land to nearly $200 \mathrm{~m}$ at J. P. Koch Fjord and over $300 \mathrm{~m}$ in Nyeboe Land.

Lithology. This prominent carbonate-rich, yellow or yellow-brown weathering formation contrasts strongly with the black or dark grey mudstones, cherts and shaly carbonates of the Henson Gletscher Formation beneath and the Amundsen Land Group above (Fig. 6b). The Kap Stanton Formation is dominated by dark grey or black argillaceous dolomites or limestones. The proportion of siliciclastic mud to carbonate mud is variable both vertically and laterally in the formation. The dark carbonaterich mudstones typically show parallel lamination but in some sections laminated carbonates alternate with paler, burrowed carbonate mudstones producing a distinctive banded structure on a decimetre to metre scale.

At the type locality (Fig. 7), the formation is carbonaterich relative to eastern outcrops and consists of thin, nodular or parallel-bedded argillaceous lime mudstones and dolomites interbedded with clast-supported carbon- ate breccia beds and thin graded skeletal-peloidal packstone or grainstone beds (Figs 8-11). Medium-grained to fine-grained, well-rounded quartz sand forms an important component in the middle of the type section (Fig. 8, 113-192 m), occurring both as discrete sandstone turbidites and as matrix in breccia beds. The nodular carbonates commonly display slope creep deformation structures such as pull-aparts, brittle slumps and interstratal breccia lenses and bands (Fig. 11). Partially dolomitised argillaceous nodular carbonates often weather to a striking orange-dark grey banding - the 'tiger limestones' of Dawes (1976). The clast composition of the mass flow breccia beds (Fig. 10) is closely comparable to the associated in situ nodular and thin-bedded lime mudstones suggesting derivation from the outer shelf, off-platform region. However, the type section of the Kap Stanton Formation also includes a large (c. $20 \mathrm{~m}$ diameter) platform-derived olistolith of light grey stromatolitic limestone (Fig. 8).

Farther east, the succession is less varied, being composed largely of dark grey to black argillaceous carbonate mudstones or marlstones, interbedded with rare units of ripple cross-laminated peloidal grainstone/packstone and prominent carbonate breccia beds, typically up to $10 \mathrm{~m}$ thick. The mass-flow breccia beds are commonly more varied in composition than those at the type section, often containing quartz sand and equidimensional metre-sized blocks of light-coloured carbonate of probable platform origin in addition to the dominant nodular or platy lime mudstone clasts. A prominent and laterally persistent breccia bed occurs near the top of the formation in the Navarana Fjord to outer J. P. Koch Fjord area (Fig. 5a). 
Boundaries. The Kap Stanton Formation lies conformably between the dark mudstones, cherts and carbonates of the Henson Gletscher Formation beneath and the Amundsen Land Group above (Figs 5, 6b). The base is placed where thin-bedded or nodular argillaceous carbonate mudstones overlie recessive-weathering, shaly black mudstones and cherts with subordinate lime mudstones. In places (e.g. north Lauge Koch Land), the basal bed of the formation is a thick carbonate breccia bed.

The top is placed where prominent-weathering argillaceous platy carbonates (or marlstones) are succeeded by black cherts and shaly mudstones assigned to the Amundsen Land Group.

Distribution. The Kap Stanton Formation crops out in thrust slices and anticlinal fold closures near the north coast of North Greenland from north-west Peary Land in the east to northern Nyeboe Land in the west (Fig. 1).

Fauna and age. The boundaries of the Kap Stanton Formation are demonstrably diachronous (Fig. 4); the formation has a maximum proven age range of medial Middle Cambrian to early Ordovician. Although fossils have not been collected in the type section, rich trilobite faunas are known from the lower beds in nearby sections in northern Nyeboe Land (locality 2 in fig. 1 of Babcock, 1994a, b and Robison, 1994; see Higgins et al., 1992). Associated with trilobites in these collections are bradoriids, inarticulate brachiopods and conodontomorphs. The trilobite faunas indicate a medial Middle Cambrian (Ptychagnostus atavus Zone) age for the basal strata in this area, as is also indicated by the uppermost collections from the Henson Gletscher Formation at the type locality of the
Kap Stanton Formation (see discussion above, Babcock, 1994a, b and Robison, 1994). To the east of outer J. P. Koch Fjord, however, the lower strata of the formation are of probable late Middle Cambrian age; rich trilobite faunas indicative of the Lejopyge laevigata Zone of the latest Middle Cambrian were collected from c. $20 \mathrm{~m}$ above the base of the Kap Stanton Formation (see Babcock, 1994a, b; Robison, 1994) where they are associated with siliceous sponge spicules.

Much of the middle Kap Stanton Formation is unfossiliferous but shaly black argillaceous carbonates and marlstones towards the top of the formation yield graptolites of Ordovician age (Bjerreskov, 1989; Smith \& Bjerreskov, 1994). West of Navarana Fjord, the uppermost beds of the formation contain Llanvirn graptolites (Bjerreskov in Higgins et al., 1992). In other sections, however, such as in north-eastern Nyeboe Land and easternmost outcrops, graptolites from the overlying Amundsen Land Group indicate a late Tremadoc age for the top of the Kap Stanton Formation. Higgins et al. (1992) suggested that the Kap Stanton Formation may extend up into the late Ordovician in north-west Nyeboe Land.

Facies and depositional environment. The Kap Stanton Formation is laterally more varied than the underlying formations and records deposition in a variety of outer shelf environments. In the type area (Figs 7,8 ), nodular or parallel thin-bedded, variably dolomitised argillaceous limestones dominate the formation; they typically show parallel lamination but are locally bioturbated. This facies primarily represents hemipelagic suspension deposits but probably also includes lime mud turbidites. Pull-aparts, inter-stratal brecciation and brittle slump folds testify to

Fig. 10. Clast-supported limestone breccia bed composed of angular platy lime mudstone clasts in a lime grainstone matrix. Note the coarsetail grading and bedding-parallel orientation of elongate clasts in the upper half of the bed. Kap Stanton Formation, type section (c. $100 \mathrm{~m}$ above base), northern Nyeboe Land.

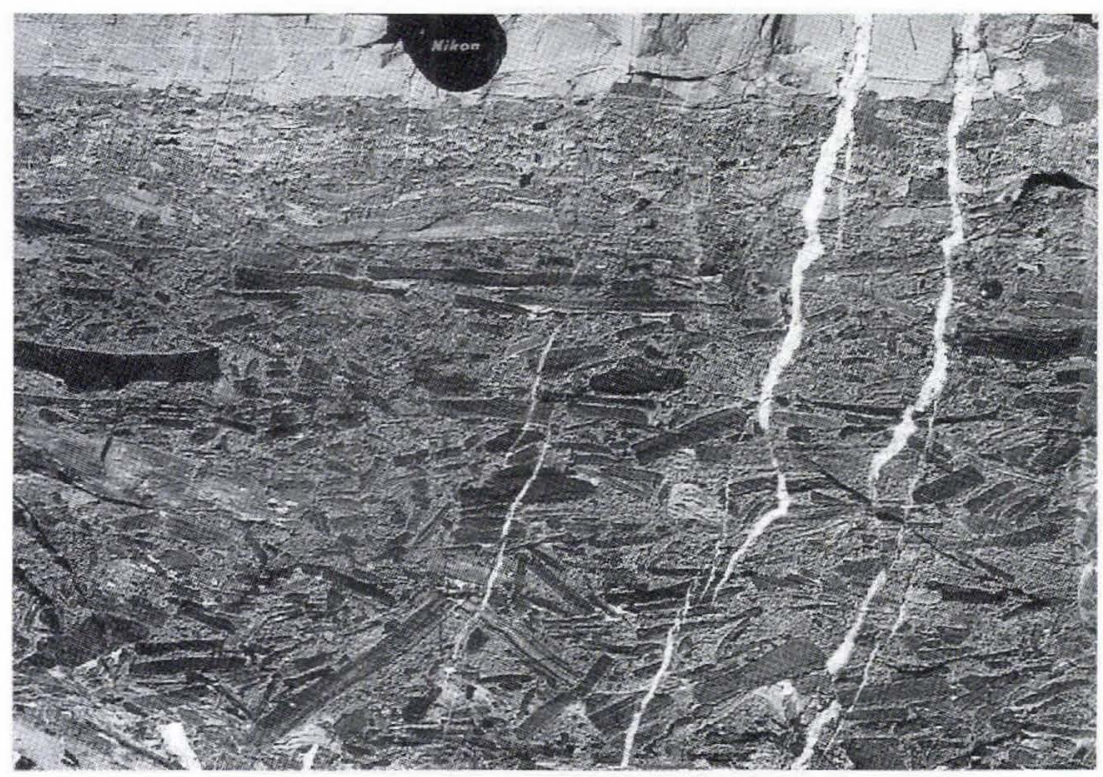




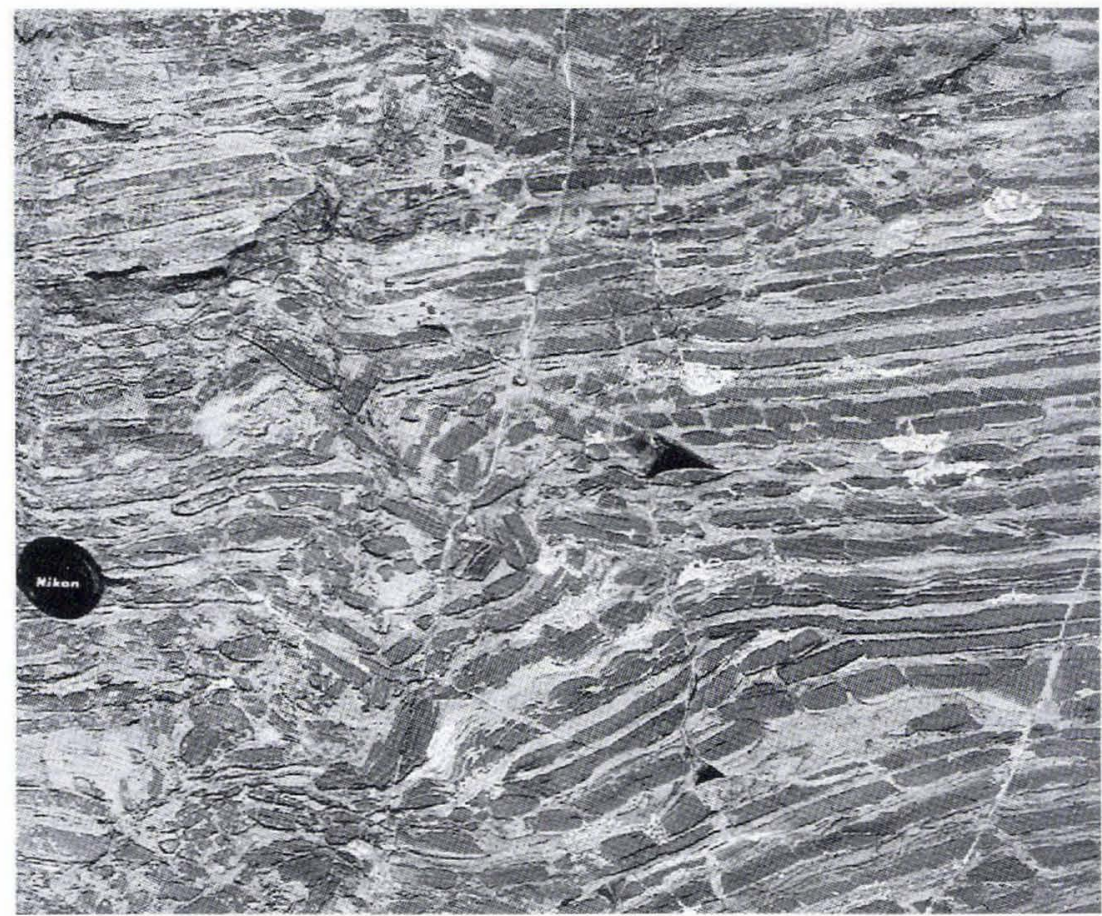

Fig. 11. Platy nodular argillaceous lime mudstones, partially dolomitised. Note the pull-aparts and brittle slump folds of inferred slope creep origin. Kap Stanton Formation, type section (c. $50 \mathrm{~m}$ above base), northern Nyeboe Land. accumulation on a depositional slope. Graded, ripple cross-laminated packstones and grainstones, graded sandy breccias and muddy carbonate breccia beds record deposition from a range of sediment gravity flow processes. Breccia clasts are largely of off-platform origin but also include blocks derived from the coeval platform margin.

The Kap Stanton Formation in northern Nyeboe Land thus records deposition in a sub-wavebase, low-energy setting that typically received carbonate sediment in the form of hemipelagic suspension deposits, turbidites and mass-flow deposits. Evidence of a depositional slope is common and the overall setting is interpreted as a carbonate slope apron, deposited seaward of the shallow-water carbonate platform.

In eastern sections (Fig. 5a), variably dolomitised dark marlstones and argillaceous limestones dominate the formation; these become graptolitic in the upper part and primarily record deposition of clay-sized and silt-sized carbonate and siliciclastic sediment from suspension. Although typically parallel-laminated, local intervals show a distinctive rhythmic alternation of laminated and weakly bioturbated beds on a scale of $10-100 \mathrm{~cm}$. Rare units of cross-laminated peloidal grainstone and packstone were deposited from tractional bottom currents; unpublished palaeocurrent data indicate shelf-parallel currents. The Kap Stanton Formation in its eastern outcrop, therefore, records deposition in a low-energy, poorly oxygenated deep shelf setting; the low carbonate content relative to the Nyeboe Land section indicates a more distal, outermost shelf environment, beyond or at the limit of carbonate dispersal from the shallow-water platform.

\section{Palaeogeography and platform evolution}

The northern outcrop of the Brønlund Fjord and Tavsens Iskappe Groups provides an extra dimension to the reconstruction of Cambrian palaeogeography in North Greenland. The southern outcrop belt documents the transition from shallow-water platform through platform margin and foreslope to carbonate slope apron and proximal outer shelf settings (Ineson, 1985, 1988; Higgins et al., 1991a). The data presented here and by Higgins et al. (1992) allow northward extension of this palaeogeographic transect from the distal slope apron to the deep outermost shelf. A condensed succession of black shaly mudstones and cherts with rare carbonate debris beds was recorded from thrust slices along the northern coastline of North Greenland (Higgins et al., 1992); these strata may extend the transect to the shelf edge or the upper basin slope.

The Brønlund Fjord and Tavsens Iskappe Groups in the northern outcrop belt record an oblique section across the outer shelf. The more proximal sections relative to the shallow-water platform occur in the west, in Nyeboe Land (Figs 1, 5b). Here the succession is nearly $500 \mathrm{~m}$ thick and is carbonate-dominated with sandstone interca- 
Fig. 12. Schematic block diagram showing the inferred late Middle Cambrian palaeogeography in western and central North Greenland (view from north). A and B indicate the locations of the sections in Fig. $5 \mathrm{a}, \mathrm{b}$, respectively. BF, Buen Formation; BFG, Brønlund Fjord Group; TIG, Tavsens Iskappe Group; RGG, Ryder Gletscher Group.

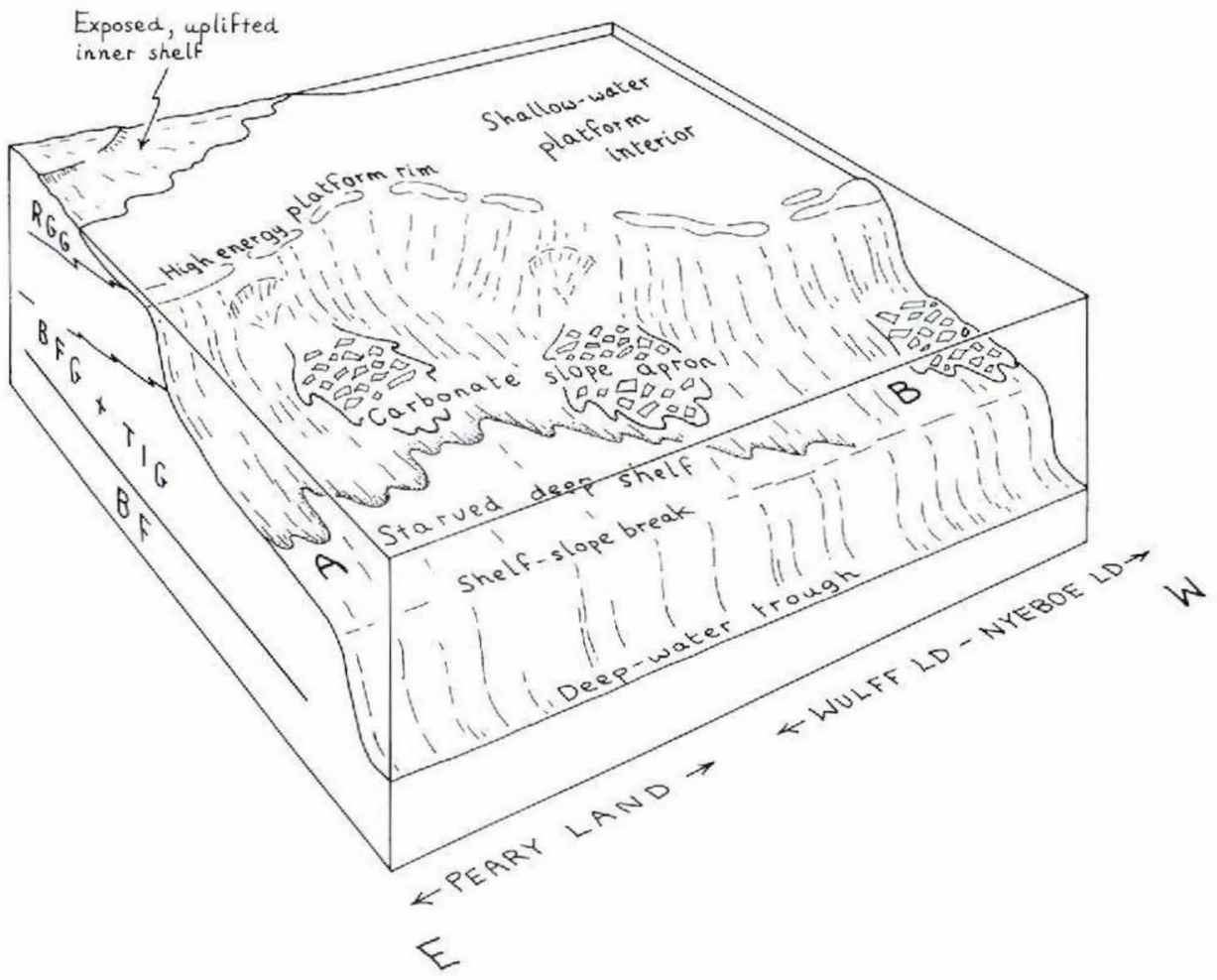

lations at a number of levels. The abundance of coarsegrained sediment gravity flow deposits and evidence of slope creep processes, particularly in the Kap Stanton Formation, indicate deposition in a slope apron setting. In the east, in contrast, the succession is typically 200-350 $\mathrm{m}$ thick and is clay-rich with only rare, thin sandstone intercalations (Fig. 5a); a distal outer shelf setting is indicated, generally beyond the range of coarse-grained sediment gravity flows derived from the upper slope apron and the platform margin to the south. Figure 12 is a schematic representation of the palaeogeography during the late Middle Cambrian showing the inferred location of the sections at Hand Bugt in the west (Fig. 5b) and outer J. P. Koch Fjord in the east (Fig. 5a).

In the J. P. Koch Fjord area, both the shelf edge and the platform margin can be accurately located (see e.g. Fig. 3 ). In the late Middle Cambrian, for example, the outer shelf was $70-80 \mathrm{~km}$ wide; the shelf edge lay about $20-30$ $\mathrm{km}$ north of the outer J. P. Koch Fjord section (Figs 1, 5a) whilst the prograding platform margin was situated at the head of J. P. Koch Fjord, approximately $50 \mathrm{~km}$ south of the section (see Fig. 12). The palaeogeography of the western area is less well-constrained since neither the platform margin nor the shelf edge can be recognised; the former is covered by younger strata and the latter is inferred to lie north of the present coastline (Figs 1, 3).
The evolution of the platform can be inferred, however, by analogy with the eastern succession.

Despite the lateral variation in thickness and facies from east to west, the overall stratigraphy of the northern outcrop is remarkably uniform, suggesting that platform evolution in the west followed a similar pattern to that recorded in the east (Ineson, 1985, 1988; Ineson \& Peel, 1987; Higgins et al., 1991a). Indeed, the Aftenstjernes $\emptyset$ and Henson Gletscher Formations at Hand Bugt in northern Nyeboe Land (Figs 1, 5b) are comparable both in thickness and overall facies development to the type sections of these formations at the head of J. P. Koch Fjord, some $250 \mathrm{~km}$ to the east (see fig. 22 in Ineson, 1980; Ineson \& Peel, unpublished). This suggests that these uppermost Lower-Middle Cambrian sediments at Hand Bugt were deposited some 10-20 km north of the platform margin, which was probably a progradational, depositional margin (sensu McIlreath \& James, 1979) at this time, as observed in the east (Ineson 1985, 1988; Ineson \& Peel, 1987).

The Kap Stanton Formation at Hand Bugt, Nyeboe Land can be subdivided into three discrete intervals that record discrete phases or events in platform evolution. The lower unit (Fig. 8, 0-113 m) is carbonate-dominated and includes abundant, thick carbonate debris sheets and turbidites; this interval records a period of extensive shedding of fine-grained sediment from the coeval plat- 
form and progradation of the slope apron by sliding and resedimentation of peri-platform fines. This style of sedimentation is well-known from eastern outcrops where it can be correlated with periods of platform progradation (Ineson \& Peel, 1987; Ineson, 1988; Higgins et al., 1991a). It can be suggested, therefore, that during the late Middle to Late Cambrian, the western platform continued to prograde northwards, possibly extending as far north as the Navarana Fjord lineament (Fig. 1).

The middle unit of the Kap Stanton Formation at Hand Bugt (Fig. 8, 113-192 m) is characterised by the appearance of medium-grained to fine-grained, well-rounded quartz sand, occurring both as discrete sandstone turbidites and as matrix in thick sandstone-dolomite debris beds. Such facies have been recorded from approximately the same level in most sections through the formation (Fig. 5a, $180 \mathrm{~m}, 220 \mathrm{~m}$; Higgins et al., 1992). It is probable that this incursion of siliciclastic sand onto the outer shelf was related to the northward and westward progradation of quartz sands during the Late Cambrian and earliest Ordovician associated with the culmination of uplift of the eastern shelf (Surlyk \& Hurst, 1984; Surlyk, 1991). In western Peary Land and Freuchen Land, the Perssuaq Gletscher Formation records the northward progradation of sandstones into the outer shelf environment (Surlyk \& Ineson, 1987) whereas the Permin Land Formation, and the correlative Kap Coppinger Member of the Cass Fjord Formation, record the westward extension of these sands across the shallow-water platform of western North Greenland (Bryant \& Smith, 1990). The eastern shelf was largely exposed at this time (see Figs 2, 12), and siliciclastic sand bypassed the shelf to form the basinal sandstone turbidites of the Vølvedal Group, in Johannes V. Jensen Land (Surlyk \& Hurst, 1984; Higgins et al., 1991a). The sandstones of the Kap Stanton Formation thus mark a significant stage in the evolution of the shelf when much of the eastern portion of the platform was exposed and thus producing little carbonate sediment. Sedimentation on the carbonate platform in the west was apparently continuous but productivity was probably reduced due to the siliciclastic influx, resulting in a decrease in the export of carbonate sediment to the deep shelf and a slowing or cessation of platform progradation.

The upper $150 \mathrm{~m}$ of the Kap Stanton Formation in the type section (Fig. 8) show an upward decrease in the proportion of carbonate mudstone relative to siliciclastic mudstone, and an overall decrease in both thickness and abundance of coarser resedimented carbonate deposits. This overall upward decrease in the proportion of carbonate is a feature of the Kap Stanton Formation throughout its outcrop (see Fig. 5 and Higgins et al., 1992) and reflects a general decrease with time in the carbonate export potential of the shallow-water platform. This may have resulted from decreased productivity of the platform but the preservation of a thick Cambro-Ordovician carbonate platform succession in central and western North Greenland (Higgins et al., 1991a) makes it more likely that the decrease records a shift in the style of platform growth. The nature of the latest Cambrian - Early Ordovician platform margin is unknown since it is nowhere exposed in North Greenland. It is clear from the Cambrian and Middle Ordovician - Lower Silurian record of platform evolution, however, that this period marked a shift from a progradational style during the Cambrian to an aggradational style during the latter part of the Ordovician and the Early Silurian, when the platform margin was anchored by differential subsidence across the Navarana Fjord lineament (Hurst \& Surlyk, 1983; Surlyk \& Hurst, 1984; Higgins et al., 1991a; Surlyk \& Ineson, 1992).

The gradual upward decrease in carbonate in the uppermost Cambrian to Lower Ordovician strata of the Kap Stanton Formation probably records this shift in platform margin development from progradational to aggradational, possibly initiated by the onset of differential subsidence along the Navarana Fjord lineament in the latest Cambrian.

Acknowledgements. The field data were collected during the latter phase of the North Greenland Project (1978-1985) undertaken by the Geological Survey of Greenland (GGU); we gratefully acknowledge the leadership of Niels Henriksen and the support of our colleagues in the field. Work on the Cambrian of the southern outcrop belt by J. R. I. was supported by a CASE studentship from the Natural Environment Research Council (U.K.). J. S. P. acknowledges support from the Natural Science Research Council (NFR) of Sweden during the preparation of the manuscript.

\section{References}

Babcock, L. E. 1994a: Polymeroid trilobites from the Henson Gletscher and Kap Stanton formations (Middle Cambrian), North Greenland. Bull. Gronlands geol. Unders. 169 (this volume).

Babcock, L. E. 1994b: Biogeography and biofacies patterns of Middle Cambrian polymeroid trilobites from North Greenland: palaeogeographic and palaeo-oceanographic implications. Bull. Gronlands geol. Unders. 169 (this volume).

Blaker, M. R. 1991: Early Cambrian trilobites from North Greenland. Unpublished Ph.D. thesis, Keele Univ., 286 pp.

Bendix-Almgreen, S. E. \& Peel, J. S. 1988: Hadimopanella from the Lower Cambrian of North Greenland: structure and affinities. Bull. geol. Soc. Denmark 37, 83-103.

Bjerreskov, M. 1989: Ordovician graptolite biostratigraphy in North Greenland. Rapp. Grønlands geol. Unders. 144, 17-33. Bryant, I. D. \& Smith, M. P. 1990: A composite tectonic-eustatic origin for shelf sandstones at the Cambrian-Ordovician 
boundary in North Greenland. J. geol. Soc. Lond. 147, 795809.

Christiansen, F. G., Nøhr-Hansen, H. \& Nykjær, O. 1987: The Cambrian Henson Gletscher Formation: a mature to postmature hydrocarbon source rock sequence from North Greenland. Rapp. Gronlands geol. Unders. 133, 141-157.

Dawes, P. R. 1976: Precambrian to Tertiary of northern Greenland. In Watt, W. S. \& Escher, A. (ed.) Geology of Greenland, 248-303. Copenhagen: Geol. Surv. Greenland.

Dawes, P. R. \& Peel, J. S. 1984: Biostratigraphic reconnaissance in the Lower Palaeozoic of western North Greenland. Rapp. Gronlands geol. Unders. 121, 19-51.

Friderichsen, J. D., Higgins, A. K., Hurst, J. M., Pedersen, S. A. S., Soper, N. J. \& Surlyk, F. 1982: Lithostratigraphic framework of the Upper Proterozoic and Lower Palaeozoic deep water clastic deposits of North Greenland. Rapp. Gronlands geol. Unders. 107, $20 \mathrm{pp}$.

Frykman, P. 1980: A sedimentological investigation of the carbonates at the base of the Brønlund Fjord Group (EarlyMiddle Cambrian), Peary Land, eastern North Greenland. Rapp. Grønlands geol. Unders. 99, 51-55.

Håkansson, E., Heinberg, C. \& Stemmerik, L. 1991: Mesozoic and Cenozoic history of the Wandel Sea Basin area, North Greenland. Bull. Grønlands geol. Unders. 160, 153-164.

Higgins, A. K. \& Soper, N. J. 1985: Cambrian - Lower Silurian slope and basin stratigraphy between northern Nyeboe Land and western Amundsen Land, North Greenland. Rapp. Grønlands geol. Unders. 126, 79-86.

Higgins, A. K., Soper, N. J. \& Friderichsen, J. D. 1985: North Greenland fold belt in eastern North Greenland. In Gee, D. G. \& Sturt, B. A. (ed.) The Caledonide orogen - Scandinavia and related areas, 1017-1029. London: John Wiley \& Son Ltd.

Higgins, A. K., Ineson, J. R., Peel, J. S., Surlyk, F. \& Sønderholm, M. 1991a: Lower Palaeozoic Franklinian Basin of North Greenland. Bull. Grønlands geol. Unders. 160, 71-139.

Higgins, A. K., Ineson, J. R., Peel, J. S., Surlyk, F. \& Sønderholm, M. 1991b [issued 1992]: Cambrian to Silurian basin development and sedimentation, North Greenland. In Trettin, H. P. (ed.) Geology of the Innuitian orogen and arctic platform of Canada and Greenland, 111-161. Geology of Canada 3. (Also The geology of North America E.) Ottawa: Geological Survey of Canada.

Higgins, A. K., Soper, N. J. \& Davis, N. C. 1992: Lower Palaeozoic outer shelf and slope lithostratigraphy, Franklinian basin, North Greenland. Open File Ser, Gronlands geol. Unders. 92/8, $57 \mathrm{pp}$.

Hurst, J. M. \& Surlyk, F. 1983: Initiation, evolution and destruction of an early Paleozoic carbonate shelf, eastern North Greenland. J. Geol. 91, 671-691.

Ineson, J. R. 1980: Carbonate debris flows in the Cambrian of south-west Peary Land, eastern North Greenland. Rapp. Grønlands geol Unders. 99, 43-49.

Ineson, J. R. 1985: The stratigraphy and sedimentology of the Brønlund Fjord and Tavsens Iskappe Groups (Cambrian) of Peary Land, eastern North Greenland. Unpublished Ph.D. thesis, Keele Univ., 310 pp.

Ineson, J. R. 1988: Lithostratigraphy and depositional setting of the Holm Dal Formation (Middle Cambrian), central North Greenland. Meddr. Gronland Geosci. 20, 9-21.

Ineson, J. R. \& Peel, J. S. 1980: Cambrian stratigraphy in Peary Land, eastern North Greenland. Rapp. Gronlands geol. Unders. 99, 33-42.

Ineson, J. R. \& Peel, J. S. 1987: Cambrian platform-outer shelf relationships in the Nordenskiöld Fjord region, central North Greenland. Rapp. Gronlands geol. Unders. 133, 13-26.

Ineson, J. R. \& Peel, J. S. unpublished: Cambrian shelf stratigraphy of the Peary Land region, central North Greenland. Manuscript for Grønlands Geologiske Undersøgelse.

McIlreath, I. A. \& James, N. P. 1979: Carbonate slopes. In Walker, R. G. (ed.) Facies models, 113-143. Geoscience Canada.

Palmer, A. R. \& Peel, J. S. 1979: New Cambrian faunas from Peary Land, eastern North Greenland. Rapp. Gronlands geol. Unders. 91, 29-36.

Peel, J. S. 1974: Lower Cambrian fossils from Nyeboe Land, North Greenland fold belt. Rapp. Grønlands geol. Unders. 65 , 17 only.

Peel, J. S. 1979a: Cambrian - Middle Ordovician stratigraphy of the Adams Gletscher region, south-west Peary Land, North Greenland. Rapp. Gronlands geol. Unders. 88, 29-39.

Peel, J. S. 1979b: Serrodiscus from northern Nyeboe Land, North Greenland. Rapp. Gronlands geol. Unders. 91, 116 only.

Peel, J. S. 1994: An enigmatic cap-shaped fossil from the Middle Cambrian of North Greenland. Bull. Gronlands geol. Unders. 169 (this volume).

Peel, J. S. \& Larsen, N. H. 1984: Hadimopanella apicata from the Lower Cambrian of western North Greenland. Rapp. Grønlands geol. Unders. 121, 89-96.

Peel, J. S., Conway Morris, S. \& Ineson, J. R. 1992: A second glimpse of Early Cambrian life: new collections from Sirius Passet, North Greenland. Rapp. Grønlands geol. Unders. 155 , 48-50.

Resser, C. E. 1939: The Ptarmigania strata of the northern Wasatch Mountains. Smithson. Misc. Collns 98(24), 72 pp.

Robison, R. A. 1994: Agnostoid trilobites from the Henson Gletscher and Kap Stanton formations (Middle Cambrian), North Greenland. Bull. Gronlands geol. Unders. 169 (this volume).

Smith, M. P. \& Bjerreskov, M. 1994: The Ordovician System in Greenland. Int. Union geol. Sci. Publ. 29A, 1-46.

Soper, N. J. \& Higgins, A. K. 1990: Models for the Ellesmerian mountain front in North Greenland: a basin margin inverted by basement uplift. $J$. struct. Geol. 12, 83-97.

Stemmerik, L. \& Håkansson, E. 1991: Carboniferous and Permian history of the Wandel Sea Basin, North Greenland. Bull. Grønlands geol. Unders. 160, 141-151.

Surlyk, F. 1991: Tectonostratigraphy of North Greenland. Bull. Gronlands geol. Unders. 160, 25-47.

Surlyk, F. \& Hurst, J. M. 1983: Evolution of the early Paleozoic deep-water basin of North Greenland - aulacogen or narrow ocean? Geology 11, 77-81.

Surlyk, F. \& Hurst, J. M. 1984: The evolution of the early Paleozoic deep-water basin of North Greenland. Bull. geol. Soc. Am. 95, 131-154. 
Surlyk, F. \& Ineson, J. R. 1987: Aspects of Franklinian shelf, slope and trough evolution and stratigraphy in North Greenland. Rapp. Grønlands geol. Unders. 133, 41-58.
Surlyk, F. \& Ineson, J. R. 1992: Carbonate gravity flow deposition along a platform margin scarp (Silurian, North Greenland. J. sed. Petrol. 62, 400-410. 